\title{
HOW INNOVATION ENCOURAGES SELF EFFICACY TO SUPPORT BUSINESS START UP SUCCESS?
}

\author{
Sri Nathasya Br Sitepu*)1 \\ *) Program Studi Manejemen, Fakultas Ekonomi Universitas Ciputra Surabaya \\ UC Town Citraland Surabaya, 60219
}

\begin{abstract}
A business start up is identical to a new business run by an entrepeneur to gain profit. The research is to analyze the function of the entrepreneurship training given by Universitas Ciputra Surabaya to the villagers in Desa Mojowarno. The objectives of the research are: 1) to learn the proper innovation technique to increase the self efficacy of the entrepreneur/participant, 2) to understand the impact of the increased self-efficacy towards the business continuity managed by the entrepreneur/participant. The research method used is qualitative descriptive analysis with the subject of the research are entrepreneurs (ten training participants) who managed banana trunk chips in Mojowarno. The validation technique used in this research is triangulation data method with participative observation, in depth interview and documentation (photo and video of the participants'capability). The result of the research: 1) Innovation realization (5+1 concept) succeeded in increasing the self efficacy of the participants (ten training participants); 2) The self-efficacy increase provides a positive impact (business increase) so that the entrepreneur has an additional income. It is suggested that the entrepreneur must keep on innovating innovated to increase their self-efficacy so that the business can improve the continuity.
\end{abstract}

Keywords: descriptive qualitative, innovation, self-efficacy, business entrepreneur start up, training

\begin{abstract}
ABSTRAK
Start-up bisnis identik dengan usaha baru yang dijalankan oleh seorang entrepreneur untuk mendapatkan keuntungan. Penelitian ini menganalisis peran pelatihan kewirausahaan yang diberikan Universitas Ciputra Surabaya kepada masyarakat Desa Mojowarno. Tujuan penelitian ini terdiri dari: 1) mengetahui teknik yang tepat untuk berinovasi guna meningkatkan self-efficacy dari entrepreneur/peseta yang mengikuti pelatihan, 2) Mengetahui dampak dari peningkatan self-efficacy terhadap keberlangsungan bisnis yang dijalankan oleh entrepreneur/ peserta pelatihan kewirausahaan. Metode penelitian menggunakan analisis kualitatif deskriptif dengan subjek penelitian adalah entrepreneur(sepuluh orang peserta pelatihan kewirausahaan) yang menjalankan bisnis keripik bonggol pisang di Mojowarno. Teknik validasi dalam penelitian menggunakan metode triangglasi data dengan observasi parisipatif, wawancara mendalam, dan dokumentasi (foto dan video kemampuan peserta). Hasil penelitian: 1) Realisasi inovasi(konsep 5+1) berhasil mendorong peningkatan self-efficacy dari entrepreneur(sepuluh peserta pelatihan), 2) Peningkatan self-eficacy memberikan dampak positif(peningkatan bisnis) sehingga entrepreneur(peserta pelatihan) sudah memiliki pendapatan tambahan. Saran bagi entrepreneur harus terus berinovasi untuk peningkatan self-efficacy sehingga peningkatan bisnis terus berlangsung.
\end{abstract}

Kata kunci: kualitatif deskriptif, inovasi, self-efficacy, start-up bisnis, entrepreneur, pelatihan

${ }^{1}$ Corresponding author:

Email: nathasya.sitepu@ciputra.ac.id 


\section{INTRODUCTION}

The business development in Indonesia has not commonly prevalent one of the place is a village called Mojowarno in Jombang district, East Java. The business growth in this village is relatively slow which affects the prosperity level of the people. The government through the infrastructure development tries to increase the prosperity of the people like providing highway as an alternative way from Surabaya to Kediri and it proofs to have increased the prosperity of Mojowarno. The evidence of economy growth is by the presence of businesses, dominated by food and beverages vendors surrounding the alternative high way. The presence of vendors who have already gained profit gives a strong motivation to the people around Mojowarno village to find and start a new business that they can realize.

The economy condition of the people in Mojowarno village is has become an economy development study conducted by Ciputra University, with regard to micro economy which can be developed by the local community. The observation is carried out for six months and succeeded in finding the banana trunk chips development potency as a predominance product of Mojowarno village potency. Banana trunk chips are originated from the trunk (root of the banana). There are three aspects that make banana trunk chips able to develop as predominance product; 1) the abundant availability of the banana trunk which can ensure the raw material for banana chips. 2) Human resource that consists of unemployed people and housewives who require extra income to fulfill their family's needs. 3) The target market of the chips is youngsters, adults and children who like snacks. In reality the markets in Mojowarno sell various kinds of snacks. The center of souvenir in Mojowarno provides snack from agriculture products such as corn, mango, and banana.

The agriculture product potential in Mojowarno is encouraged to innovate accurately so the product manufactured has a high added value. Fontana (2011) defined that innovation is socially and economically successful after finding, creating and introducing/ applying new ways or combination and previous ways in transforming input into output in such a way that it can create a positive major change in comparing the benefit values to the price. Innovation is the realization of someone's change of behavior if they are able to focus in $5+1$ stage which is the behavior key for innovation. Miller and Wedellsborg (2013) tried to defined 5+1 concept that is: a) Focus, b) Connect, c) Tweak, d) Select, e) Stealthstorm, f) Persist from the leader so they can have people do the five behavior key through communication.

A successful innovation will increase the self-efficacy capacity from an individual. Referring to Bandura (1986) the term self-efficacy is defined as an individual self-confident of his capacity to organize and execute a set of action to achieve a certain goal. Inggarwati and Arnold (2012) in their research found out that the full factor levels that experienced an increase during a business establishment and as well as the entrepreneur's self-efficacy, make the process of building a business has a greater level of intention to develop the business. Leon and Justin (2017) stated that self efficacy is someone's confidence in believing he has the capability to perform an act which will bring a specific result. This is an important construction in entrepreneurship which has proven to have two direct effects, short term and long term not only in the intention to establish a new business but also in the behavior.

Self-efficacy entrepreneur affects the continuity on the conducted business. The proof on the self-efficacy increase on the entrepreurship was presented by Shah et al. (2015) who in his research discovered that selfefficacy in UKM Melayu in Shah Alam location is a mediator that is able to relate the personal value to entrepreneurship orientation. Malaysia's UKM has a high self efficacy and entrepreneurship orientation enhancement. Prabhu et al. (2012) discovered that entrepreneurial self-efficacy has a very important role so that many educational institutes give entrepreneurship training based on either knowledge or field practice.

Liu et al. (2017) discovered the significant modernization effect of self efficacy to POS relation to performance. Self efficacy is important is line with Stemberger (2008) finding who stated that orientation towards business transaction leads to the increase/ improvement of non financial performance and indirectly affects the business achievement. The selfefficacy measurement technique on the research object is based on the observation on their ability to make decisions. Diana and Jennings (2014) in their research learned that the entrepreneurial self efficacies (ESE) in younger women are significantly lower. This is because of the minimum experience in entrepreneurship which can be positive or negative in operating the business. The non financial factor is also evaluated 
of each individual/entrepreneur based on entrepreneur characteristic to describe the motivation to become an entrepreneur (Inggarwati and Arnold, 2012).

The entrepreneurship training participant understanding in the innovation concept is able to increase the selfefficacy so that the banana trunk chips business is also increasing. The training participants require training on production and entrepreneur capacity development. The Ciputra University has given the second phase training for the people in Mojowarno. The first training is focused on the product development and financial aspect. This is because the price arranged for the products is related to the financial aspect. While in the second training which is conducted for one year is focused on developing the capacity of the participants. The second training is grouped into non financial factor because it is not related to expenses. The outcomes of the two trainings are to increase the success of the entrepreneur as training participant.

The entrepreneurship training (first and second training) given by Ciputra University is beneficial to the economy of the Mojowarno community. The benefit of the training is in accordance with the research result conducted by Matlay (2008) stated that entrepreneurship education has a positive effect to the achievement of the entrepreneurial results. The benefit of the training is also found by Peter and Quan (2015). He pointed out that training on business is able to increase the micro business performance and has other positive results such as, increasing motivation, success, and businessman perception. Rauth (2014) research result presented that the existence of suitable education/training, assisted the participants in obtaining innovative ideas and converting them in the business/company. It takes three months for the development product of banana trunk chips that was conducted in the first phase training. The objective of the banana trunk chips training has become very important and in accordance with Molaei et al. (2014) finding on the objective of an entrepreneurship program that it has to becomes an idea for students to develop an entrepreneurialship. Specifically Fernando and Jayawarna (2011) pointed out that the participants have the feeling of post-training creative ability and enable them to obtain a positive result. This is in accordance with Wiska et al. (2016) finding that looked into the public school program which can be used for partnership to renew the mindset of breeders. Trainings are also provided by the Department of Cooperatives and UMKM (Small Micro Business) Sidoarjo to encourage the people to start entrepreneurship. Rosianti (2014) also explained that the effort carried out by the Department of Cooperatives and the UMKM Siodarjo in organizing education and training is already good, as proved in the existence of training facilities, the availability of practicing equipment simulation media, training materials, consumption, special training and other supporting facilities that enable to motivate the training participants to enhance their entrepreneurship. Kumalasari (2014) clarified the effort of Disko Perindag (Cooperatives, Trade and Industry Department) and ESDM (Ministry of Energy and Mineral Resources) to support the jetis batik industry growth that is considered optimal, even though it is not evenly spread, because not all the batik craftsmen in Jetis village have attended the training, hence the batik craftsmen who have attended the training have the industrial increase It is not only productivity enhancement, but training on financial management is also highly required. Maulani et al. (2016) revealed, having a simple financial record, the business actors have a new perspective and are motivated to manage their business well. The function of the training in business development is very strategic therefore Ciputra University Surabaya provided a second phase training to the Mojowarno community. The second phase training is focused on the innovation to encourage the self-efficacy of the training participants so they can support the start-up business success of the banana trunk chips in Mojowarno.

The training is collaboration between Ciputra University and banana trunk chips entrepreneur startup. The objective of the collaboration is to develop the start-up business. The importance of this collaboration is supported by the research conducted by Sucipto et al. (2015) which explained that authority and partnership effects mushroom business performance. It is similar to the research by David and Battisti (2016). In his research he discovered the conceptual frame that showed three areas which influences entrepreneurship skills: the relationship with national cooperative, the relationship with the institutional regulatory environment and the relation with the economic market environment. The result from various researches is the reason for Ciputra University to continue the training to the second phase which is based on innovation to improve self-efficacy of the entrepreneurs through establishing a cooperation/ partnership with people of Mojowarno. 
The elaboration of some research about innovation and self-efficacy concept is able to push the business success into an important base. The research analysis on the success of applied innovation is to encourage self-efficacy so it can increase the business success of the second phase training participant. This research attempts to formulate the problems as follows: How to apply innovation to enhance the self-efficacy of the entrepreneurs who participate in the entrepreneurship training conducted by Ciputra University Surabaya? Than, how is the impact of self-efficacy enhancement to the continuity of the banana trunk chips start up business in Mojowarno?

\section{METHODS}

The research is conducted in Mojowarno village, Jombang District, and East Java Province for one year (2014-2015). The data used in the research is primary data which is gathered from business observation and in depth interviews with the entrepreneurs who are the training participants of the second phase training in Mojowarno village The method used is descriptive qualitative where this research will not determine based on research variable but based on the social condition observed among others: location aspect, object and synergic interaction. The research chose the descriptive analysis variable because the research object needs to be described in detail and needs more length of time, to find the solution to overcome the research problem. The understanding of descriptive qualitative is more influenced by deductive-descriptive perspective (Bungin, 2103). The research object is banana trunk chips business start-up which is managed by the entrepreneurship training participants. The research subject is ten business start-up owners who attend the training. The populations of the research subject are men and women entrepreneurs aged 39-49 years. The research subject was determined through a series of identification stages, conducted by the researchers, they are consisted of: 1) the research subjects are startup business entrepreneurs who have passed the first phase of entrepreneurship training; 2) the research subjects are training participants/banana trunk chips entrepreneur who still operate their business/still and earn monthly minimum revenue of Rp1.000.000; 3) the training/entrepreneur participants are obliged to pass an interview stage with the training facilitators who then evaluate the capacity of the research subject physiologically to upgrade the self-efficacy of each training participant (research object). The outcome of the last stage is a commitment from the research object to participate in the second phase training which will be focused on innovation aspect, self-efficacy and the increased success in banana trunk chip business.

The data respondent is obtained through in depth interview to each of the respondent regarding the innovation aspect, self-efficacy aspect and business success. The data measurement technique is carried out through observation on how far the innovation is realized. The research is to learn more of the innovation concept $5+1$ in business conducted by the entrepreneurs whether it is wholly done or partially and the concrete form of the innovation component. The result will then be compared with the financial report owned by each business. The information obtained from the respondent is then analyzed to look into the role of the innovation aspect in encouraging self-efficacy to create a successful business.

The data analysis stage is conducted in three important stages. The first stage is the observation process of the research object, to observe intensively the role and the development of self-efficacy from each research subject within one year. The observation on the research object success is conducted by preparing a table consists of the revenue, cost, profit, number of consumers and marketing area of the banana trunk chips within one year. The second stage is the result of the observed data that is tested for validation shows how far the test is or a set of measurement operation of on what should be measured (Jogianto, 2011). The research result validation used triangulation technique whereas the collected data combines various techniques of data collection and data source. The triangulation method use participative observation, interview and documentation (photo and video). The third stage is the triangulation that result is processed and analyzed to find the solution in increasing the success of the startup business of banana trunk chips in Mojowarno. The innovation success indicator in the start-up business of banana trunk chips can be measured from the implementation of the concept variable $5+1$ consists of: Focus. Stealthstorm, Persist, Connect, Tweak and Select. Data analysis model in Fifuge 1. 
The implementation of the second phase entrepreneurship training involved eleven facilitators (lecturers). This program gave an understanding on innovation concept with the aim to increase the entrepreneurs' self-efficacy so that they can support the success of the banana trunk chips start-up business. The training is conducted once a week every Saturday and starting from 08:00-15:00. The facilitators observe the application of $5+1$ concept in the entrepreneurship training. The $5+1$ innovation concept is a research aspect; on how far are the roles in each factor on the success of the start-up business. Every facilitator conducted in-depth interview with the research subject (entrepreneur) who are the training participants. The activities in the entrepreneurship training was documented and the interview result will be collected as analysis materials in implementation and influence of research factor (concept 5+1) in encouraging selfefficacy towards business success.

In this research stage, an analysis is carried out in the second phase entrepreneurship training given by Ciputra University to the banana trunk chips entrepreneur start-up business participants that have already passed the first phase training. The next step is analyzing the innovation concept $5+1$ used to increase the entrepreneurial self-efficacy which is expected to support the success of the business. The appraisal for the success of the start-up business is based on the innovation concept realization used in the business operation. The research framework is in Figure 2.

\section{RESULTS}

\section{The innovation to enhance Self-efficacy in the Entrepreneurs}

The innovation implementation through the second phase entrepreneurship training by Ciputra University with participants 7 female entrepreneurs and 3 male entrepreneurs is focused on $5+1$ concept to enhance self-efficacy to achieve the business growth. The number of participants are dominant by women this is in accordance with Sweida and Rebecca (2013) research result that discovered the gender role and the negative stereotype has an effect towards self-efficacy while carrying out the entrepreneurship and the women's interest to start a business experienced high growth.

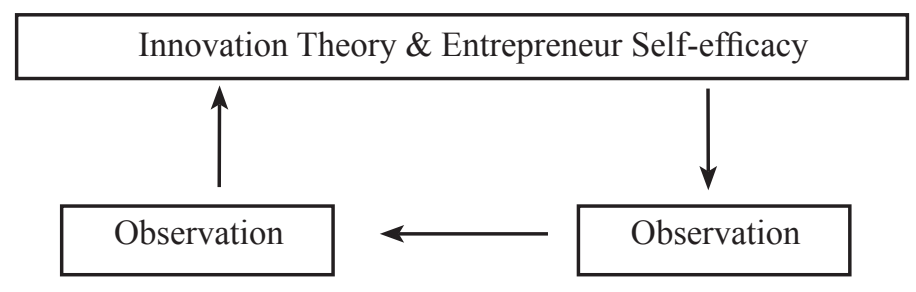

Figure 1. Data analysis model

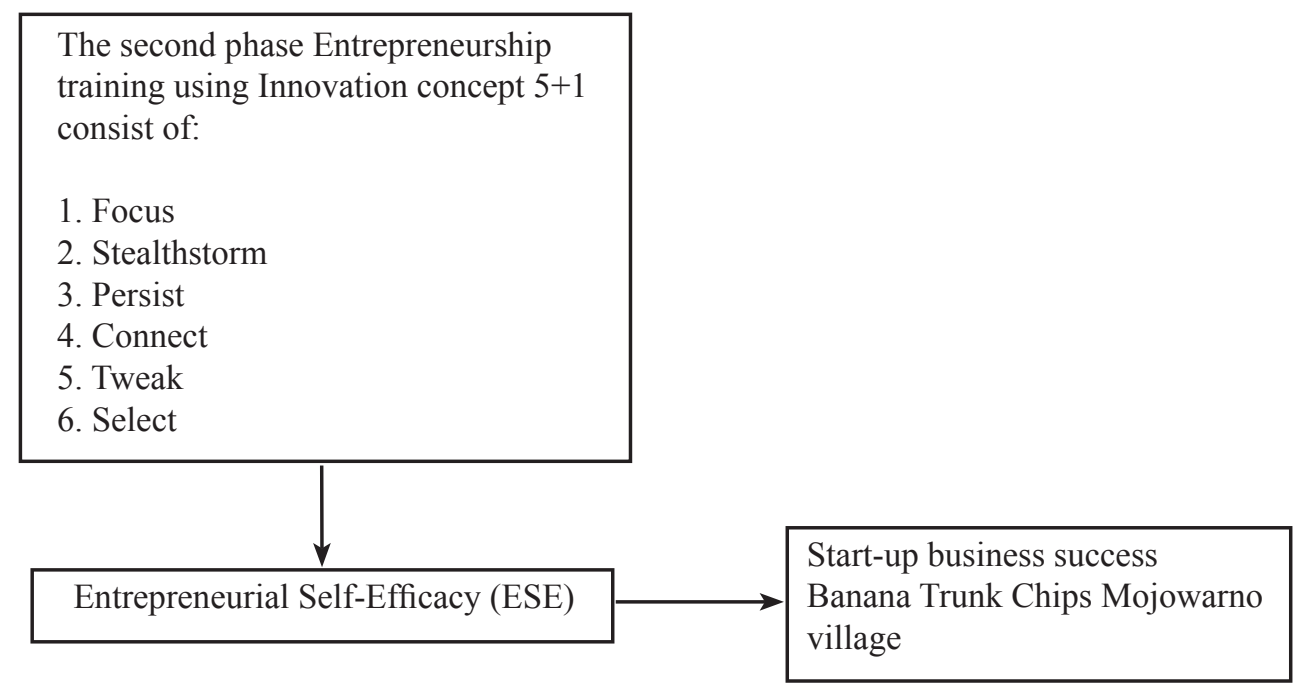

Figure 2. Research framework 
The research result is divided into 6 components that match the amount of concept $5+1$. The analysis result of the first concept is related to "Focus" concept, training participants (entrepreneur); at the beginning the training participants are asked to arrange a minimum of two concepts of development related to their business. Then the participants continued to analyze the concept using a minimum of two business analysis tools (SWOT and PEST). Then the entrepreneur choose the best result, meanwhile during the arrangement and recovering process the participants are accompanied by the facilitators (lecturers from Ciputra University). This stage is the most difficult stage where the facilitators are encouraged to give a comfortable feeling between the participants (entrepreneur) and the facilitators. The innovation in this stage used media like diagram, mind map and other tools in order to simplify the participants to express their concept and analysis.

The result of the second concept is connect; through the participant's ability to connect the available input capacity (resources, capital, technology, etc). The training participants are asked to elaborate the input availability possessed by the entrepreneur. Input from minimum two business process sources (external and internal). The participants were asked to describe the business flow especially the production flow from the input to the output (banana trunk chips product). Facilitator accompanied. The participants carried out the implementation of the connect concept through the prepared work sheet that should be filled out. The training participants were separated based on their business type (each business type one facilitator). The facilitators will give stimulus questions to the participants so they will understand the input until the output flow of the managed business.

The third concept is tweak. The tweak carried out by the participants appeared when the participants were conducting the connect concept. The training participants simulated each of the focus the concept from the first to the second. The facilitator stimulated the participants by giving the economy condition facts which affected by the participants' ongoing start-up development business. The economy fact given to the participants such as the UMR level in Jombang regency, the inflation level, and the government policy related to business legality. The training participants finally can produce a simulation to anticipate the problems that may happen due to the influence of the economic condition (UMR level, inflation and the government policy). The result of the modification/ simulation business increased the self-efficacy ability of the participants. This is proven by the existence of ideas from the participants to modify their business to overcome economy condition.

The fourth concept is the ability to select. When the first, second until third concept is done well, it is then continued by selecting the innovation concept from the beginning. Finally the participants at the start-up business were able to choose the most rational idea with the optimum achieved success. The participants realized their ideas (make a rectangular and circle product); the participants realize the marketing idea only by conducting an exhibition, through resellers and finally using pre-order system. The marketing idea used social media and personal approach. All the realized ideas have a positive influence to increase the amount of selling and an increased profit as the final outcome. When the entrepreneurs succeeded in realization their ideas, their self-efficacy also increases. Figure 3 shows documentation of the location, where the facilitators stimulate the participants through questions so that the participants are able to choose the optimum idea to be realized.

The fifth concept is focus to the stealthstrom that describes the situation of an organization that in this case is the start-up business. The participants are able to negotiate with external party (outside the business). The banana trunk chips entrepreneurs are able to negotiate with the government by taking care of the PIRT documents at the industry service agency Jombang regency. The non government parties who also negotiate with the entrepreneur are the resellers where the banana trunk chips are sold. The negotiations with these resellers cover the procedure activities in depositing the banana chips, payment system and returning the remaining system. The negotiations conducted by the participants are priory trained by the facilitators in the communication training. The objective of the communication training is to make the participants able to conduct business negotiation. The fifth concept could be realized if the entrepreneur performs the first until the fourth concept well. 

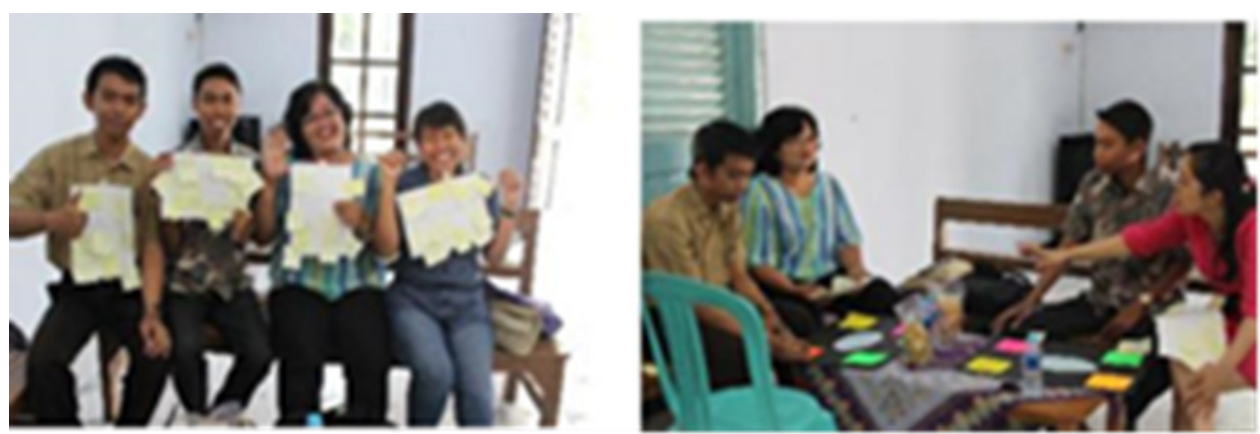

Figure 3. Implementation of select concept documentation

The sixth concept is persistent. This concept is the core of the other five concepts. All other five concepts (focus, connect, tweak, select, stealthstorm) have to be carried out synergistically. The five concepts are implemented based on the sixth concept. The proof of the participants' consistency are observed from several facts, they are, participants/entrepreneur still run the business even though there is no training, the entrepreneur look for relations with external parties (government, resellers, exhibition committee, etc). The participants are still persistent in finding creative ideas to increase business. The persistent of the participant are vulnerable especially when the resellers return their product (banana trunk chips). This is when the facilitators give encouragement even though it needs extra training duration.

The entrepreneur (ten research subject) conducted the innovation concept $(5+1)$ wholly so that they are successful in increasing the self-efficacy of each training participant. The ten participants who attended the first training only possess the self-efficacy during the training, when the first phase training was finished, the self-efficacy of the participants started to decrease in performing the business. The entrepreneurs, who attended the second phase training, possess higher self-efficacy during and after the training are over. The enhanced entrepreneurs' self-efficacy is reflected in the business activities; they become more focus and approach the business goal that was set from the beginning.

The effect of Self-Efficacy increase in the continuity of the start-up business (Banana Trunk Chips) in Mojowarno

Ten (10) entrepreneurs as the research subjects have implemented the innovation concept and they undergone an increase in which brought positive impact towards the continuity of the start-up business (banana trunk chips) in Mojowarno, proven by the growth of the business. The ten training participants are able to establish cooperation with new external parties. The self-efficacy of the participants is the base for the entrepreneur to develop the business. The development of the start-up business organized by the ten entrepreneurs can be classified into marketing and production aspect.

The female training participants actualized their selfefficacy through business development by adding product variant of the taste of the chips. The female participants produce many variants flavor for their banana trunk chips to present alternatives to the consumer. One of the participants succeeded in producing meatballs (baso) and shredded meat (abon) originated from banana trunk. The female training participants (entrepreneur) not only adding variants but alsodistributed the product through community network. The female entrepreneur joins the women creativity group (PKK), religious group, and UMKM community nurtured by the local government of Jombang regency. The female self-efficacy entrepreneur simplifies their interaction especially in distributing their product (banana trunk chips) and other variants. The female entrepreneur brought their sample products and gave it for free. The educating process related to the benefit of the banana trunk chips were also introduced by the entrepreneur to the expected consumer.

As a result, the social community became a loyal consumer of the banana trunk chips. The majority of the social community is in Mojowarno and its surroundings yet these communities recommended the banana trunk chips to their social networks outside Mojowarno, Resulting in personal orders for the banana trunk chips outside of the town. The number of orders for the banana trunk chips received by the 
women entrepreneur is about 100-200 packages every week but in the holiday season in can double. There is a difference in the amount of product compared to when they attended the first phase training which was only about 50-100 packages every week. The male training participants distributed the product by maintaining relationship with stores in Mojowarno therefore the number of banana trunk chip sales is around $50-100$ packages per week.

The self-efficacy possessed by the entrepreneur as the participants in the second phase entrepreneurship training, has really increased the start-up growth of the banana trunk chip growth in Mojowarno. The training participants (entrepreneur) received extra earnings to support the family economy. The extra earnings gained by each of the entrepreneur will increase the economy growth of the villagers including utilizing the waste of the banana tree as a source of economic value. Receiving extra income as the training benefit for the participants who produces banana trunk chips is in accordance to the research result of Putri and Warianto (2014) where the training in screen painting and clothes sewing give a positive impact (increase the employee performance productivity) besides that all the motivation statements that the employee received from the UMKM employee it also increased the productivity (work result).

The result of the research supported by Putri and Warianto's research result (2014) is evidence on how important training is to increase the capacity of a community (especially the training participants). The entrepreneurship training participants in Mojowarno are still focused on snack industry of banana trunk chips moreover the training participants shared the innovation concept in increasing the self-efficacy to the people living around Mojowarno. The people are enthusiastic to develop the business by exploiting the potency around the village. The spirit of the training participants is the evidence that innovation is capable to increase the self-efficacy of the participants and also giving impact to the community outside the training area. This is also in accordance with the research finding of Rauth (2014), that a suitable education assists them in finding an innovative idea and changing the idea in a company. The training gives an impact in the selling of banana trunk chips, now the banana trunk chips are well known in Jombang regency and have become the specific snacks and a tourist must buy food.

\section{Managerial Implications}

The entrepreneur conducting the start-up business required knowledge and realization of the innovation concept of $5+1$. The $5+1$ concept that consists of: Focus, Stealthstorm, Persist, Connect, Tweak and Select must be operated as a whole by an entrepreneur in order to provide an optimal result. The entrepreneurship training given to the entrepreneur start-up should have $5+1$ concept so that the innovation is able to operate maximally through self-efficacy increase. The training gave the innovation concept starting with focus aspect so that the entrepreneurs have a strong base to do innovation.

\section{CONCLUSIONS AND RECOMMENDATION}

\section{Conclusions}

The innovation implementation that encourages self efficacy is important to the success of the start-up business. Innovation realization is proven through the participant's readiness in making a change and implementing $5+1$ concept in the start-up business. The innovation training succeeded in encouraging the participants' self-efficacy so that the banana trunk chips business in Mojowarno village increases.

The entrepreneurs who posses self-efficacy succeeded in managing the start-up business of banana trunk chips. The success of the entrepreneur (the participant of the second phase training) can be seen by the increase in the number of production and distribution location. Self-efficacy is a strong base for the entrepreneur to develop their business with external parties (consumers and suppliers). The entrepreneurs who are the training participants have influenced the other villagers in Mojowarno village to open a new business opportunity and utilize the natural resources in Mojowarno village.

\section{Recommendations}

Entrepreneurs must always innovate to increase their self-efficacy. The self-efficacy increase must follow the $5+1$ concept and be always escorted by a business competent facilitator. The implementation of the escort program required a long time because the impact of the self-efficacy increase towards the start up business can only be observed if the training process 
is done of minimum one year or more. The following research should be done for all kind of businesses and all business units owned by the entrepreneur from the starting business in Desa Mojowaro so that it can show the overall micro economy condition.

\section{REFERENCES}

Bungin B. 2013. Penelitian Kualitatif. Jakarta: Prenada Media Group.

David D, Battisti JBM. 2016. Entrepreneurial skill and regulation Evidence from primary sector rural entrepreneurs. International Journal of Entrepreneurial Behavior \& Research 22(2): 234-259.https://doi.org/10.1108/IJEBR-122014-0240.

Dianna D, Jennings J. 2014. Gender and entrepreneurial self-efficacy:alearning perspective. International Journal of Gender and Entrepreneurship 6(1):28-49.https://doi.org/10.1108/IJGE-022013-0013.

Fontana A. 2011. Innovate We Can! Manajemen Inovasi dan Penciptaan Nilai. Jakarta: Penebar Swadaya.

Inggarwati K, Arnold K. 2012. Peranan Faktor-Faktor Individual dalam Mengembangkan Usaha Studi Kuantitatif pada Wirausaha Kecil di Salatiga. International Research Journal of Business Studies 3(2).

Jogiyanto. 2011. Pedoman Survei Kuesioner: Mengembangkan Kuesioner, Mengatasi Bias dan Meningkatkan Respon. Yogyakarta: Fakultas Ekonomika dan Bisnis UGM.

Kumalasari YY. 2014. Pembinaan dan pemberdayaan pengrajin batik (studi di Dinas Koperasi, UKM, Perindustrian, Perdagangan dan ESDM Kabupaten Sidoarjo dan Industri Kecil Kampoeng Batik Jetis Kabupaten Sidoarjo). Jurnal Administrasi Publik 2(1): 66-70.

Leon S, Justin BC. 2017. Development and validation of a unidimensional domain-specific entrepreneurial self-efficacy scale. International Journal of Entrepreneurial Behavior \& Research 23(1):98-113.https://doi.org/10.1108/IJEBR11-2015-0251.

Liu J, Cho S, Putra ED. 2017. The moderating effect of self-efficacy and gender on work engagement for restaurant employees in the United States. International Journal of Contemporary Hospitality Management 29(1):624-642. https://
doi.org/10.1108/IJCHM-10-2015-0539.

Fernando L, Jayawarna D. 2011. Enterprise education: the effect of creativity on training outcomes, International Journal of Entrepreneurial Behavior \& Research 17(3): 224-244. https:// doi.org/10.1108/13552551111130691.

Matlay H. 2008. The impact of entrepreneurship education on entrepreneurial outcomes. Journal of Small Business and Enterprise Development 15(2): 382-396. https://doi. org/10.1108/14626000810871745.

Maulani TS, Dialysa F, Prawirasasra KP. 2016. Pelatihan Pembukuan Keuangan Sederhana Dan Motivasi Kewirausahaan Pada Kelompok Usaha Makanan Rw 02 Kelurahan Neglasari Kecamatan Cibeunying Kaler Bandung, Jurnal Dharma Bhakti STIE Ekuitas 1(1): 32-37.

Miller P, Wedellsborg TW. 2013. Innovation Business As Usual How To Help Your People Bring Great Ideas To Life. Boston: Harvard Business Review Press.

Molaei R, Mohammad R Z, Mohhammad HM, Jahngir YF. 2014. The impact of entrepreneurial ideas and cognitive style on students entrepreneurial intention. Journal of Entrepreneurship in Emerging Economies 6(2): 140-162. https://doi. org/10.1108/JEEE-09-2013-0021.

Putri SA, Warianto W. 2017. Pengaruh Pelatihan dan Kalimat Motivasi Terhadap Produktifitas Kerja Karyawan UMKM. Optima 1(1): 60-71.

Prabhu VP, Stephen J. McGuire EA, Drost KK. Kwong. 2012. Proactive personality and entrepreneurial intent Is entrepreneurial selfefficacy a mediator or moderator?, International Journal of Entrepreneurial Behavior \& Research 18(5): 559-586. https://doi. org/10.1108/13552551211253937.

Rauth BB. 2014. Impact of education and training on performance of women entrepreneurs A study in emerging market context. Journal of Entrepreneurship in Emerging Economies 6(1): 38-52. https://doi.org/10.1108/JEEE-05-20130014.

Rosianti W. 2014. Upaya Dinas Koperasi Ukm Dalam Menyelenggarakan Pendidikan Dan Pelatihan Kewirausahaan Untuk Meningkatkan Motivasi Berwirausaha (Studi Pada Dinas Koperasi, Ukm, Perindustrian, Perdagangan dan Esdm Sidoarjo). Jurnal Administrasi Bisnis 12(1):1-8.

Peter R, Quan VLe. 2015. Teaching business skills to women Impact of business training on women's 
P-ISSN: 2407-5434 E-ISSN: 2407-7321

Accredited by Ministry of RTHE Number 32a/E/KPT/2017

microenterprise owners in Vietnam. International Journal of Entrepreneurial Behavior \& Research 21(4):622-641. https://doi.org/10.1108/IJEBR06-2014-0099.

Shah AS, Rohani MBHK, Noor GMN. 2015. Personal values and entrepreneurial orientations in Malay entrepreneurs in Malaysia Mediating role of selfefficacy. International Journal of Commerce and Management 25(4): 385-401. https://doi. org/10.1108/IJCoMA-01-2013-0001.

Sucipto E, Oktaviani R, Rizal R. 2015. The effects of partnership and entrepreneurship toward business performance of Oyster Mushroom (Pleurotusostreatus). Indonesian Journal of
Available online at http://journal.ipb.ac.id/index.php/ijbe

DOI number: 10.17358/IJBE.3.2.121

Business and Entrepreneurship 1(1):32-41. https://doi.org/10.17358/IJBE.1.1.32.

Sweida GL, Rebecca J. Reichard. 2013. Gender stereotyping effects on entrepreneurial selfefficacy and high-growth entrepreneurial intention. Journal of Small Business and Enterprise Development 20(2): 296-313. https:// doi.org/10.1108/14626001311326743.

WiskaF, Syarief R, Baga LM. 2016. Developing "sekolah peternakan rakyat" program using the business model canvas approach (case study: Bojonegoro Regency). Indonesian Journal of Business and Entrepreneurship 2(2):69-81. https://doi.org/10.17358/IJBE.2.2.69. 